\title{
Distinctive Unifacial Technology during the Early Holocene in Southern South America
}

\author{
Hugo G. Nami ${ }^{1}$, María T. Civalero ${ }^{2}$ \\ ${ }^{1}$ Department of Geological Sciences, Laboratory of Geophysics “Daniel A. Valencio”, CONICET-IGEBA, FCEN, UBA, Buenos \\ Aires, Argentina \\ ${ }^{2}$ National Institute of Anthropology and Latin American Thinking, CONICET-UBA, Buenos Aires, Argentina \\ Email: hgnami@fulbrightmail.org
}

How to cite this paper: Nami, H. G., \& Civalero, M. T. (2017). Distinctive Unifacial Technology during the Early Holocene in Southern South America. Archaeological Discovery, 5, 101-115. https://doi.org/10.4236/ad.2017.53007

Received: April 15, 2017

Accepted: July 5, 2017

Published: July 11, 2017

Copyright (c) 2017 by authors and Scientific Research Publishing Inc. This work is licensed under the Creative Commons Attribution International License (CC BY 4.0).

http://creativecommons.org/licenses/by/4.0/

\section{(c) (i) Open Access}

\begin{abstract}
The early Holocene archaeological record in Northwest Santa Cruz province in southern Argentina is remarkable in its richness. Among the lithic remains, most notable is a stemless triangular projectile point dating to $\sim 8.5-10$ uncalibrated kya. As part of a long term program directed to explore and understand diverse aspects of lithic technologies from Patagonia, this paper reports new observations on a set of notable unifacial tools existing in the assemblage accompanying them. Based on archaeological and experimental data we hypothesize they were produced from thick flake-blanks with one face totally or partially covered by flake scars sometimes reaching the longitudinal symmetry axis. This fact suggests that before being finished, it was reduced by detaching flakes from the edge to its center. This recent technological discovery allowed deepened on a new regional issue related with early Holocene unifacial tools that emerge as a peculiar style of covering unifacial flaking with subtle production differences to other similar implements. Together with the triangular points, this particular way of preforming the tool before and/or during the final shaping might be another distinctive manufacturing technique used by early Holocene hunter-gatherers in the area.
\end{abstract}

\section{Keywords}

Early Holocene, Lithic Technology, Unifacial Tools, Patagonia, South America

\section{Introduction}

Located in the Patagonian region in southern Argentine Republic, the Northwest of Santa Cruz province is a significant place in the history of the archaeology of the southern part of South America. There, an important record of hunter- 
gatherer occupations has been identified in several stratified and surface sites (e.g. Gradín et al., 1976, 1987). Since the early 1980s a long-term archaeological project has been underway in the studied area in particular (Aschero, 1981-82). Different kinds of evidence, mainly rock art, as well as faunal, botanical and lithic remains, have borne witness to the diverse topics related to the regional archaeological process (Aschero et al., 1992, 1992-93, 1996a, 1996b, 2005, 2007; Castro et al., 2012; De Nigris, 2004; Fugassa et al., 2005, 2006, 2010; Martínez Tosto et al., 2012, 2016; Sacchi et al., 2016). One of the most important focuses on this research has been lithic studies, mainly from a morpho-technological perspective (e.g. Civalero, 1995, 1999, 2000, 2009, 2016; Civalero \& Aschero, 2003; Civalero \& Franco, 2003; Civalero \& De Nigris, 2005; Civalero et al., 2007).

As part of a long term research program directed to explore and understand diverse aspects on lithic technologies from the Americas in general and Patagonia in particular, a set of unifacial tools were the subject of observational and experimental replicative studies (e.g. Nami, 2010, among many others). Hence, this paper reports the preliminary results on a specific technique of stone tool manufacture identified in the lithic assemblage used by early Holocene hunter-gatherers from southern Patagonia.

\section{Provenance of the Artifacts.}

The examined specimens come from three sites (Figure 1). Cerro Casa de Piedra $\left(47^{\circ} 57^{\prime} \mathrm{S}, 72^{\circ} 05^{\prime} \mathrm{W}\right)$ is a volcanic rhyolitic hill with several rock shelters facing northwards. It is situated in the transition ecotone of a deciduous wood and bushy steppe in the Lake Burmeister and Roble River valleys in Perito Moreno National Park (Figure 1). One of the main sites, the Cerro Casa de Piedra 7 (CCP7) cave, has a sedimentary deposit $\sim 2 \mathrm{~m}$ deep spanning the PleistoceneHolocene transition to the Late Holocene. The stratigraphic section shows 19 natural layers deposited on the cave's bedrock. Following the retreat of the local glaciers at the end of the Pleistocene, dung and bone recovered from layer 19 shows that at $\sim 10.6 \mathrm{kya}$, it was a refuge for extinct and extant fauna (the milodontidae family and Lama guanicoe). Furthermore, the archaeological remains show a long sequence of human occupation spanning 10.6 and 3.4 kya (Aschero et al., 2007), as well as a very short occupation at 1.9 kya (Civalero et al., 2006-07). The lower layers (14 to 18) at CCP7 yielded evidence of diverse topics related to hunter-gatherers living there during the initial Holocene at $~ 7.8$ - 9.6 uncalibrated kya (Civalero, 2009; Civalero \& Aschero, 2003; Civalero \& Franco, 2003; Civalero \& De Nigris, 2005), or $~ 8.5$ - 11.4 calibrated kya (Table 1).

The Milodón Norte 1 cave (CMN1, S $\left.47^{\circ} 18^{\prime} 22.4^{\prime \prime} 71^{\circ} 53^{\prime} 55.9^{\prime \prime} \mathrm{W}\right)$ is currently situated $\sim 2 \mathrm{~km}$ east of Lake Pueyrredón. However, at the time of human occupation, it was located close to the shore of an ancient paleolake (Horta \& Aschero, 2010; Horta et al., 2011, 2013; Sacchi et al., 2016). The deposit yielded vestiges of hunter-gatherers who inhabited the area up to 7.9 uncalibrated kya. Below a tephra layer deposited by one of the Hudson volcano eruptions at $\sim 6.8$ uncalibrated kya (Stern pers. comm. 2008), the lower stratigraphic layers (7 and 8) 


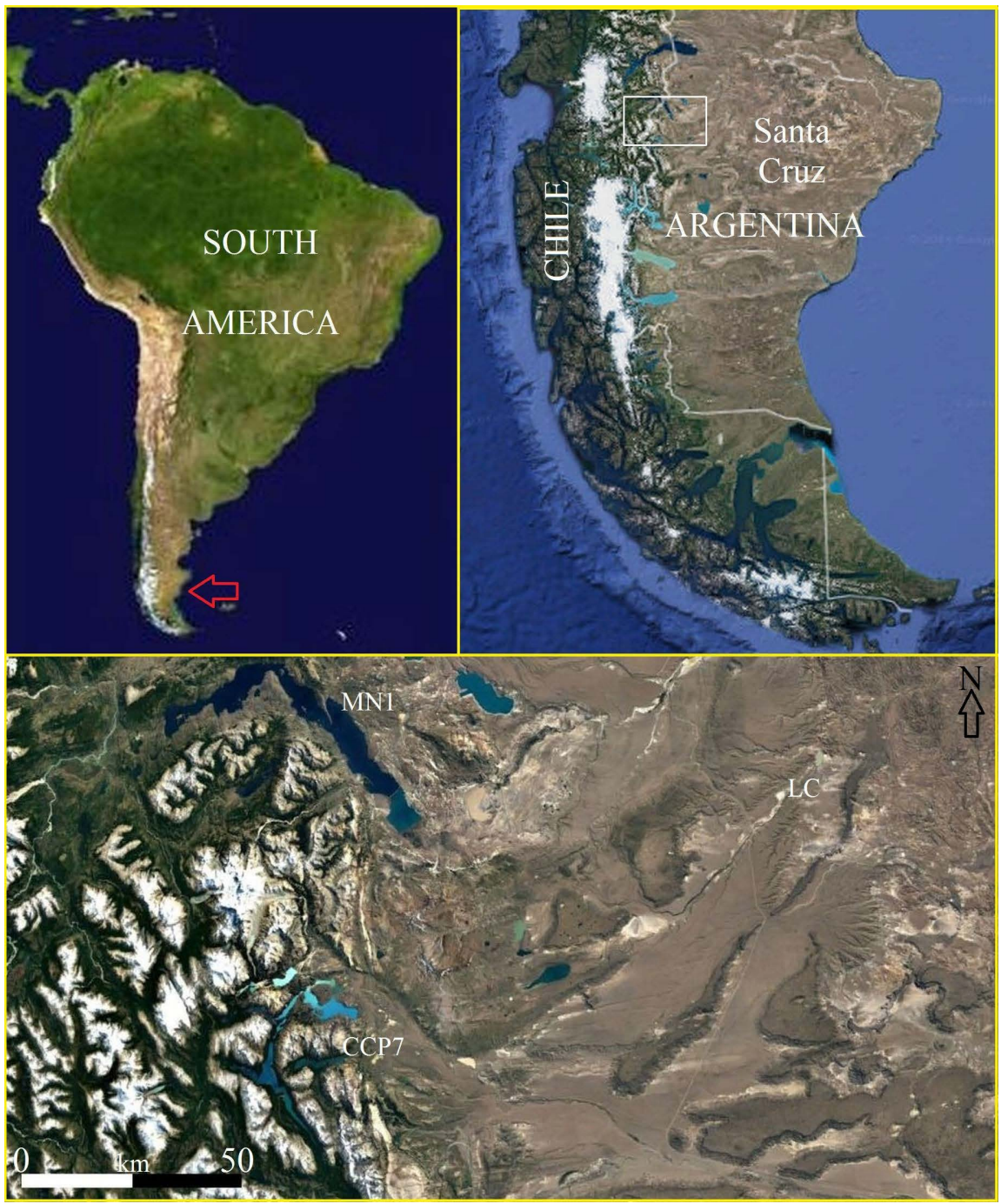

Figure 1. Map of South America and the location of Santa Cruz province and XII region in Argentina and Chile, respectively, in southern Patagonia. The Cerro Casa de Piedra 7 (CCP7), Mylodon cave north 1 (MN1) and Laguna de los Cisnes (LC) sites in Northwest Santa Cruz province, shown as a rectangle (after Google Maps, 2016).

contain the remains of the initial regional occupation. Among them, there are two remarkably large unifacial tools (Figure 2(1)) that were recovered very close to one another at the bottom of and below a large inclined rock without any contextual relationship. Due to its location, material rarity, and lack of and/or scarce use, this find was considered to be a cache (Sacchi et al., 2016). Radiocarbon assays obtained from the layers containing the remains of the initial occupations of CCP7 and CMN1 are shown in Table 1. They were corrected with the Oxcal 4.2.4 calibration program (Bronk Ramsey \& Lee, 2013) employing the ShCal13 curve for the southern hemisphere (Hogg et al., 2013).

Playa Cisnes 2 (PC2, $\left.47^{\circ} 30^{\prime} 20.8^{\prime \prime} \mathrm{S}, 70^{\circ} 34^{\prime} 27.3^{\prime \prime} \mathrm{W}\right)$ is located in a steppe environment; it is an open-air site situated on the northwest beach of the endorheic Los Cisnes lagoon. Surface and partially buried lithic finds exposed along $30 \mathrm{~m}$ showed a significant morphological variation, suggesting a palimpsest of arti- 
Table 1. List of uncalibrated and calibrated radiocarbon dates from the CMN1 and CCP7 sites.

\begin{tabular}{|c|c|c|c|c|c|c|}
\hline Site & Layer & Material & $\begin{array}{l}{ }^{14} \mathrm{C} \text { age } \\
\text { yr BP }\end{array}$ & $\begin{array}{c}\text { Cal age ranges } \\
(\text { yr BP })\end{array}$ & $\begin{array}{c}\text { Laboratory } \\
\text { number }\end{array}$ & Reference \\
\hline CMN1 & 8 & Charcoal & $7790 \pm 30$ & 8595 - $8436(95.4 \%)$ & UGAMS 4020 & Sacchi et al., 2016 \\
\hline “ & $7(2)$ & “ & $7982 \pm 45$ & $8990-8632(95.4 \%)$ & AA101222 & “ \\
\hline CCP7 & 14 & “ & $8460 \pm 400$ & $10,418-8429(95.4 \%)$ & UGA 7382 & \\
\hline “ & 15 & Twigs & $9730 \pm 100$ & $11,256-10,726(95.4 \%)$ & Beta 59925 & $\begin{array}{c}\text { Civalero \& } \\
\text { Aschero, } 2003\end{array}$ \\
\hline “ & 16 & Wood & $8920 \pm 200$ & $\begin{array}{c}10,438-9525(94.5 \%) \\
10,490-10,459(0.9 \%)\end{array}$ & UGA 7383 & “ \\
\hline “ & 17 & Charcoal & $9100 \pm 150$ & 10586 - $9700(95.4 \%)$ & LP 364 & “ \\
\hline “ & 17 & Wood & $9640 \pm 190$ & $\begin{array}{c}11,406-10,371(94.0 \%) \\
10,357-10,299(0.9 \%) \\
11,593-11,566(0.4 \%) \\
11,466-11,459(0.1 \%)\end{array}$ & UGA 7384 & “ \\
\hline “ & $17(3)$ & Bone & $9390 \pm 40$ & $\begin{array}{c}10,697-10,480(88.7 \%) \\
10,469-10,426(6.7 \%)\end{array}$ & UGA 9987 & $\begin{array}{l}\text { Civalero \& De } \\
\text { Nigris, } 2005\end{array}$ \\
\hline “ & $17(3)$ & $\begin{array}{l}\text { Extinct } \\
\text { herbivore } \\
\text { dung }\end{array}$ & $10,620 \pm 40$ & $\begin{array}{l}12,657-12,513(69.3 \%) \\
12,499-12,434(26.1 \%)\end{array}$ & UGA 9986 & $"$ \\
\hline “ & $18(2)$ & “ & $10,530 \pm 620$ & $13,712-10,561(95.4 \%)$ & UGA 7385 & $\begin{array}{c}\text { Civalero \& } \\
\text { Aschero, } 2003\end{array}$ \\
\hline “ & 19 & $\begin{array}{c}\text { Lama } \\
\text { guanicoe } \\
\text { bone }\end{array}$ & $10,690 \pm 72$ & $\begin{array}{c}12,715-12,540(81.7 \%) \\
12,496-12,435(11.7 \%) \\
12,531-12,515(2.0 \%)\end{array}$ & UGA 873 & $\begin{array}{l}\text { Aschero et al., } \\
2007\end{array}$ \\
\hline
\end{tabular}

facts of different ages. However, by the finding diagnostic tool (Figures 2(h)(i)), a significant number of finds were attributed to the initial Early Holocene occupation (Civalero, 2016).

\section{Morphological and Technological Observations}

As seen above, the archaeological record of the early Holocene human occupations in this area is remarkable in its richness. Besides the rock art (Aschero, 1981-82, 1996a), it has diverse wood, bone, and stone tool remains (Civalero, 2000, 2009, 2016; Scheinsohn, 2010; Caruso \& Civalero, 2014; Caruso et al., 2015). Among the latter, there is a distinctive stemless triangular projectile point with straight or slightly convex borders and bases (Figures 2(a)-(j)) made mainly from obsidian from the Pampa del Asador source and heat-treated chert (Civalero, 1999; Espinosa \& Goñi, 1999; Stern, 1999). Formerly identified in the Fell and Pali Aike caves as "period III" at the southern tip of Patagonia (Bird 1946, 1960), its earliest use in Northwest Santa Cruz was consistently dated at 9 - 10 kya (Gradín et al., 1987; Civalero, 2000; Cattáneo, 2006; among others). Different from points, and produced from diverse materials (obsidian, chert, basalt, among others) the assemblage accompanying them include unifacial implements characterized by their morphological and dimensional variability (Gradín et al., 1976; Aguerre, 1979), and display a wide degree of resharpening (Dibble, 1995, Baena Preysler \& Carrión Santafé, 2010). From a production viewpoint, many were simply made by short retouches on thin flake-blanks less 


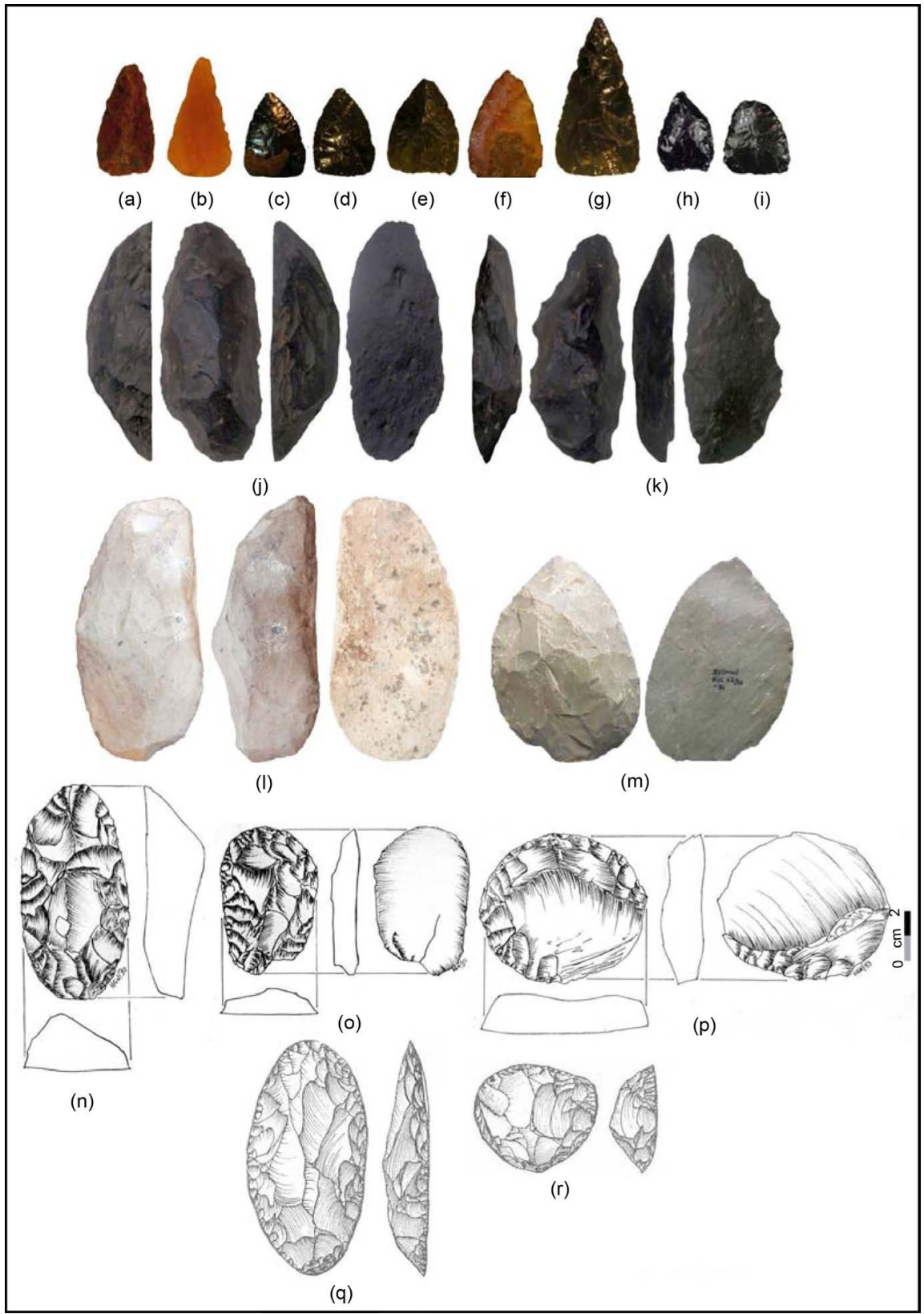

Figure 2. Early Holocene projectile points from (a-i) and unifacial tools (j)-(r). CCP7 layers 12 (a)-(e), 14 (f), 18 (g), PC2 (h) (i); (j) (k) CCP7 layers 14 and 18; (l) CMN1; (m) Alero del Valle; (n)-(p) Cueva del Medio; (q) (r) Unused and extremely resharpened scrapers from Ethiopia (after Clark, 1981: Figure 3(a) Figure 3(b)).

than $12 \mathrm{~mm}$ thick. However, at the above sites others were produced from blanks thicker than those previously mentioned (e.g. Civalero \& Franco, 2003, Civalero, 2016). Besides the flake-blanks clearly detached by direct percussion, a significant number display attributes that indicate bipolar flaking (Nami, 2000). This was used to reduce exhausted percussion cores, discarded tools used as bipolar cores, and obsidian nodules probably coming from Pampa del Asador, located $\sim 50 \mathrm{~km}$ from CCP7. A notable fact about this group of unifacial tools is that one blank's surface is totally or partially covered by flake scars that some- 
times reach the longitudinal symmetry axis. This phenomenon suggests that before finishing them with short retouches, the face was reduced by detaching flakes from the edge to its center (Figures $2(j)-(p)$ ). Different to large flake-scars resulting from shaping the working edge of a thick unifacial tool, such as scraper planes (Gradín et al., 1987: Figure 4 Figure 5), experimental research in progress has led to the hypothesis that this kind of flaking is a particular way of preforming a tool before and/or during the shaping (Figure 3 Figure 4, Nami \& Civalero, 2016). In fact, when flake-blanks are not obtained from prepared cores (e.g. Nami, 2006, 2015: Figure 7), most ordinary hard-hammer flakes have some blunt or irregular edges (Whittaker, 1994: p. 31); then, as in bifacial reduction on a large thick flake-as observed in Figures 3-5 the initial shaping must be done with the purpose of preparing an edge where one is absent, otherwise it is too sharp or low-angled for further chipping (Callahan, 1979: p. 67). Sometimes, like

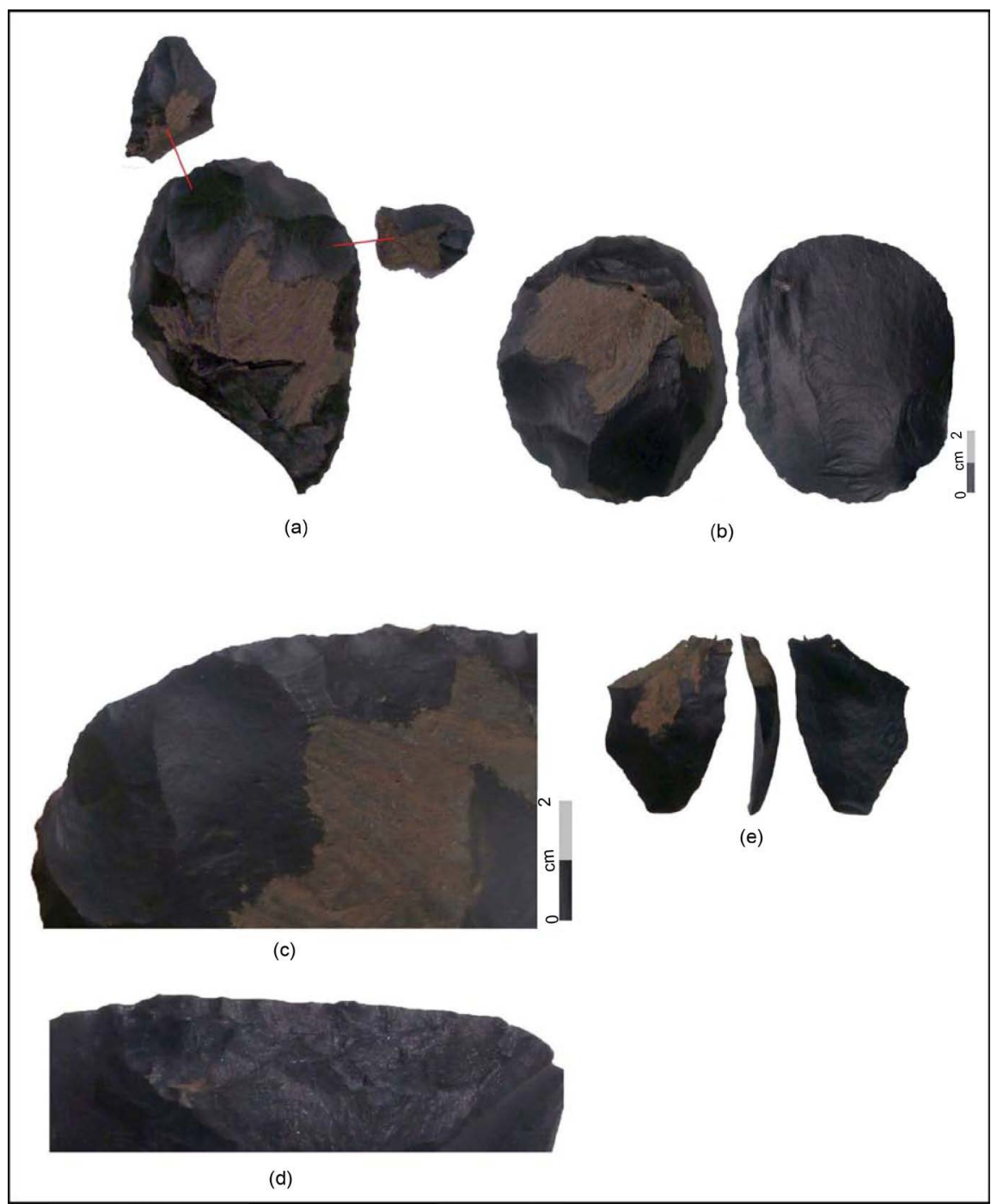

Figure 3. (a) Flake-scars and flakes detached by soft antler percussion flaking; (b) finished circular scraper with partial unifacial reduction, (c) (d) close-up of flake-scars obtained by soft (c) and hard (d) percussion flaking; (e) example of debitage obtained with an antler billet. 


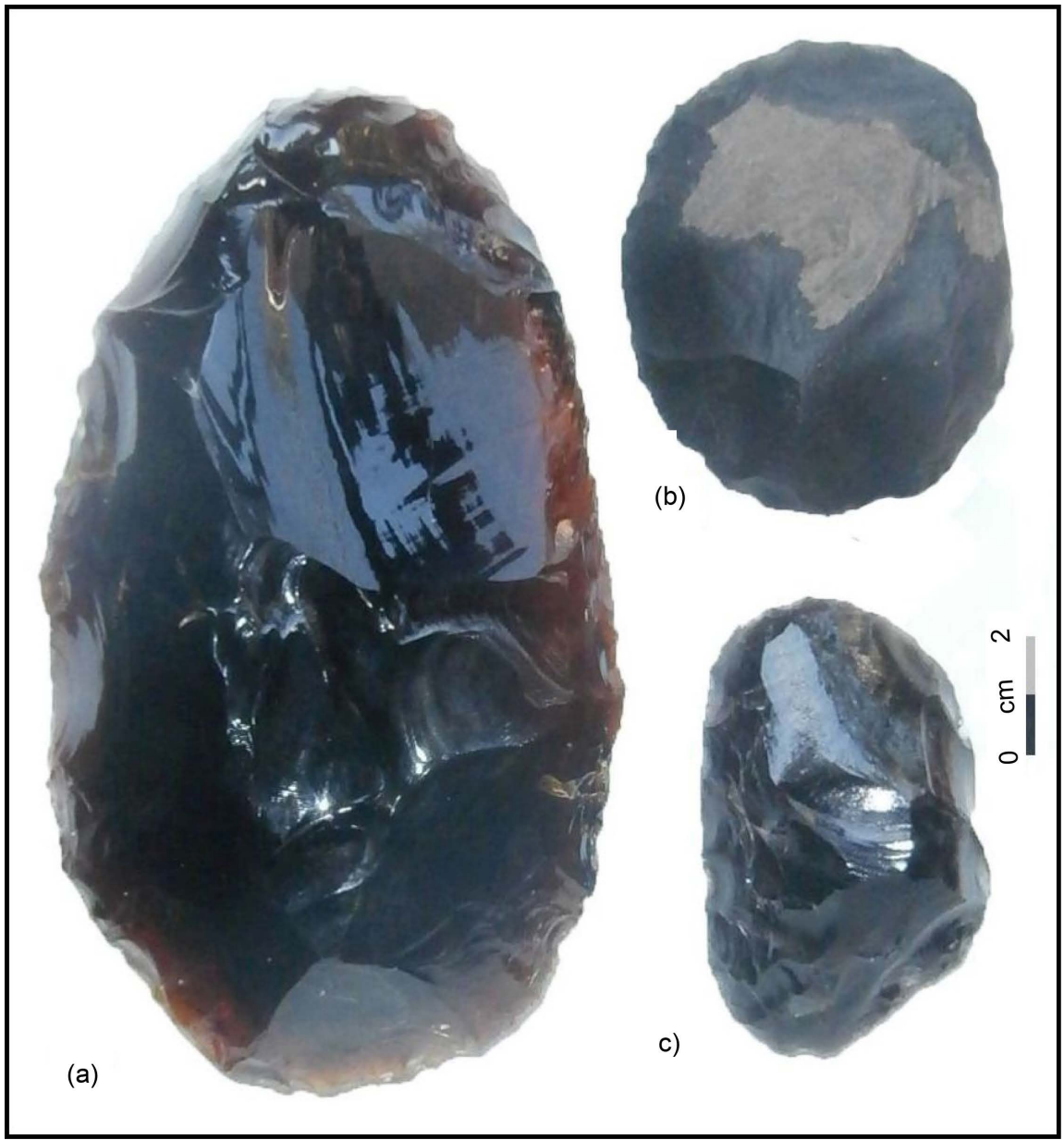

Figure 4. Examples of experimental specimens made with the technical features discussed in this paper. a) large side-scraper made on a partial bifacially reduced blank by soft percussion; (b) (c) unifacial tools flaked by hard and soft percussion flaking. Materials: (a) industrial glass; (b) dacite from Paso Limay, Río Negro, Argentina; (c) Obsidian, Maule lagoon, Chile.

standard unifacial tools (Whittaker 1994: 116-118, Figure 6.35), this step may produce edges useful for cutting or scraping (Figure 5(b)). However, after that, with the aim of forming a uniform face, before and/or during the final shaping, unifacial and/or partial bifacial reduction is performed using soft or hard percussion according to the material (Figure 3 Figure 4, Figure 5(c)). Lastly, the final shaping is done by regularizing the desired edge either by soft or hard percussion flaking. In nutshell, before and/or during retouching the functional edge, the dorsal face of the flake-blank was partially or totally reduced by detaching covering flakes from the edge to its midpoint (Figure 5(d), Nami \& Civalero, 2016). It is worth mentioning that in comparison with lithic tools of more complex production such as bifacials, in general unifacial implements show a simpler manufacturing technique. However, despite their apparent simplicity, published as well personal observations on a significant number of Patagonian end- and side-scrapers suggest that since the terminal Pleistocene to Late Holocene they exhibit diverse manufacturing strategies, and hence technological 


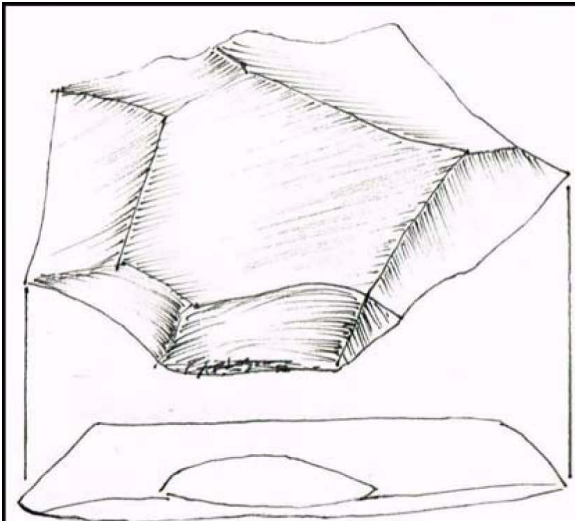

(a)

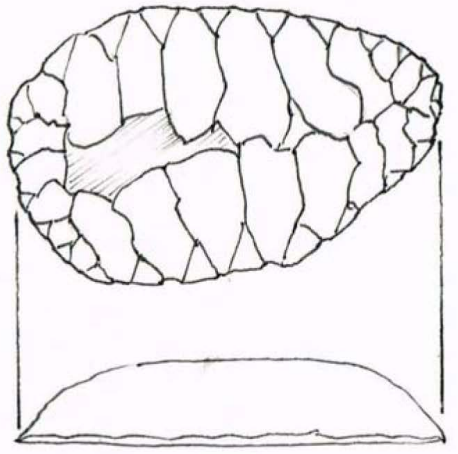

(c)

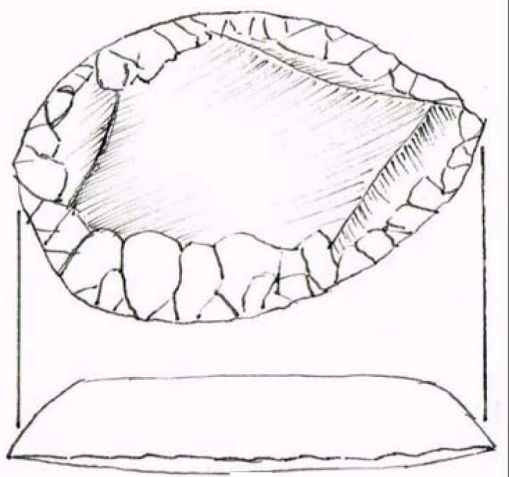

(b)

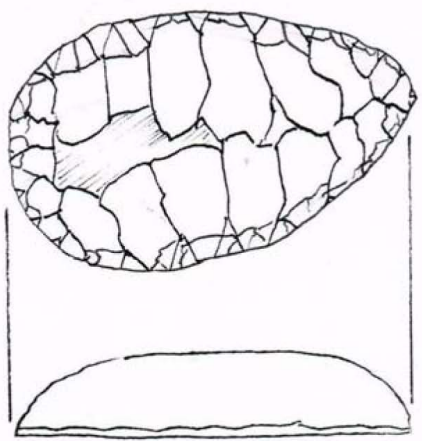

(d)

Figure 5. Schematic idealized reduction sequence of the discussed unifacial tools. (a) Flake-blank; (b) rought out or initial shaping; (c) unifacial reduction; (d) final shaping.

differences. For example, there are other reduction sequences made from flakes obtained from prepared cores (Nami, 1997, 1999: Figure 4(a)), previously bifacially reduced blanks (Nami several pers. obs.; see Aguerre, 2003: Figure 8 Figure 9), or blades and thin laminar flakes with one or two arrises (Gradín et al., 1987: Figure 22, Figure 25-27; Gradín \& Aguerre, 1994: Figure 3; Onetto, 1994). These variations might be considered stylistic (Sackett, 1982; Reedy \& Reedy, 1994; Nami, 1997-98). In fact, scraper production and manufacturing style (Weedman Arthur, 2008: p. 83) are issues that may be considered in our case (Civalero, 2016). We think that the particular way of making the tools reported here represents a particular type of technological knowledge (Schiffer \& Skibo, 1987) mainly related to its fabrication method during the early Holocene.

In light of the aforementioned facts, it was possible to identify unifacial tools with a similar manufacturing method from other sites in southern Patagonia. In the Pali Aike volcanic region in the Chico River basin, a tool with remarkable unifacial covering flaking was exhumed from the lower levels of the Alero del Valle rockshelter (Figure 2(m), Nami, 2009). Moreover, in Fell's cave there is a specimen with these features in the layer 8, associated with triangular points and dated at $6485 \pm 115$ and $6560 \pm 115$ uncalibrated radiocarbon years (Bird, 1988: Figure 76, middle row right). Cueva del Medio in southern Chile yielded similar points both on the surface and in the stratigraphy (Nami, 1987). Interestingly, 
some unifacial implements from the surface show technological similarities to those found at the sites reported above (Figure 2(n)-(p)).

\section{Concluding Remarks}

Recent discoveries and observations on a set of early Holocene unifacial tools from southern Patagonia allowed deepened on a new regional technological issue. Characterized by a uniform unifacial flaked face made before and/or during the final shaping, the described artifacts emerge as a peculiar style of covering unifacial flaking with subtle production differences to other similar tools. $\mathrm{Cu}$ riously, a resembling unifacial reduction was still in use for making certain hidescrapers in Ethiopia during the twentieth century (Gallagher, 1977; Clark, 1981; Clark \& Kurashina, 1981; Weedman Arthur, 2008). Ethno-archaeological research has revealed that during the first steps of manufacture, which were carried out in a quarry, the initial unifacial shaping was done intentionally to achieve the desired thickness and to reduce weight during transportation to the place of habitation (Gallagher, 1977: 408). Interestingly, Clark (1981: Figure 3) reported a notable unused scraper resembling certain Patagonian pieces (Figure $2(q))$. Worth mentioning that, in other areas of South America there are pieces that might be manufactured in a similar way. Actually, from the comparative lithic technology viewpoint (Nami, 1997), similar unifacial tools were employed in different part of the world. A few examples from South America come from Arroyo Seco 2 site, Buenos Aires, Argentina (Fidalgo et al., 1986: Figure 7a-b, 10a-c), and Piauí, Brazil (Pagli et al., 2016: Figure 10: 5, 11: 2, 4); Interestingly, northwest of the continent in Colombia and Ecuador, some of the so-called "plane-convex scrapers" (López Castaño, 1999: Plate 10, Figure 11-12; Bell, 1965: Figure 23(a) Figure 23(b)) or "tortoise scrapers" (Temme, 1982: 153: 1, 157) might be cited.

Finally, noteworthy that in the socio-cultural process of the southern part of South America, following the widespread use of "fishtail" or "Fell" points during the last millennium of the Pleistocene (Flegenheimer et al., 2013; Nami, 2014), in the early Holocene technological diversification can be witnessed in the employment of diverse kinds of lithic assemblages (Bueno et al., 2013; Hoguin, 2014; Lourdeau et al., 2014; Escudero et al., 2016). In Patagonia, stemless triangular projectile points have been widely used (Bird, 1988; Gradín et al., 1987; Crivelli Montero et al., 1993, Nami, 1999; Aguerre, 2003; Durán et al., 2003; Cattáneo, 2006; among others). Remarkably, their distribution extends to other areas north of this region (Restifo \& Hoguin, 2012; Cortegoso, 2014; Escola, 2014; Nami, 2014; Patané Aráoz \& Restifo, 2016). In Northwest Santa Cruz province in Southern Patagonia in particular, in addition to triangular armature tips the aforementioned unifacial tools might become another regional distinctive artifact used by early Holocene hunter-gatherers.

Ongoing research on more archaeological and experimental specimens will provide new and complementary information to understand unknown technological topics on unifacial reduction strategies in South America. 


\section{Acknowledgements}

We are deeply indebted to: CONICET, INAPL and the University of Buenos Aires of Argentina for their ongoing support. The field and laboratory work were financed by Agencia Nacional de Promoción Científica y Tecnológica Proyecto PICT No 1927 "Al oeste del río Pinturas: Poblamiento e interacciones con el área cordillerana (noroeste de Santa Cruz)" directed by C. Aschero. Christopher Ramsey was very kind and helpful during the calibration of radiocarbon dates.

\section{References}

Aguerre, A. M. (1979). Observaciones sobre la industria Toldense. Sapiens, 3, 35-52.

Aguerre, A. M. (2003). La cueva 4 de La Martita y las ocupaciones de 8000 años (Santa Cruz, Argentina). In A. M. Aguerre (Ed.), Arqueología y Paleoambiente en la Patagonia Santacruceña Argentina (pp. 27-62). Buenos Aires: Búsqueda de Ayllu.

Aschero, C. A. (1981-82). Nuevos datos sobre la arqueología del Cerro Casa de Piedra, sitio CCP5. Relaciones de la Sociedad Argentina de Antropología, XIV, 267-284.

Aschero, C. A. (1996a). A dónde van esos guanacos? In J. Gómez Otero (Ed.), Arqueología. Sólo Patagonia (pp. 153-162). Puerto Madryn: CENPAT.

Aschero, C. A. (1996b). El área Río Belgrano-Lago Posadas: Problemas y estado de problemas. In J. Gómez Otero (Ed.), Arqueología. Sólo Patagonia (pp. 17-26). Puerto Madryn: CENPAT.

Aschero, C. A., Bellelli, C., \& Goñi, R. (1992-93). Avances en las investigaciones arqueológicas en el Parque Nacional Perito Moreno (Pcia. de Santa Cruz, Patagonia Argentina). Cuadernos del Instituto Nacional de Antropología y Pensamiento Latinoamericano, 14, 143-170.

Aschero, C. A., Bellelli, C., Civalero, M. T., Goñi, R., Guráieb, G., \& Molinari, R. (1992). Cronología y Tecnología en el Parque Nacional Perito Moreno (PNPM): ¿Continuidad o Reemplazos? Arqueología, 2, 89-106.

Aschero, C. A., Bozzuto, D., Civalero, M. T., De Nigris, M., Di Vruno, Vruno Dolce, V., Fernández, N., González, L., \& Sacchi, M. (2007). Nuevas evidencias sobre las ocupaciones tempranas en Cerro Casa de Piedra 7. In F. Morello, M. Martinic, A. Prieto and G. Bahamonde (Eds.), Arqueología de Fuego-Patagonia: Levantando piedras, desenterrando huesos... y develando arcanos (pp. 569-576). Punta Arenas: CEQUA.

Aschero, C. A., Goñi, R. A., Civalero, M. T., Molinari, R., Espinosa, S., Guráieb, A. G., \& Bellelli. C. (2005). Holocenic Park: Arqueología del Parque Nacional Perito Moreno. Anales de Parques Nacionales. Naturaleza y Cultura, XVII, 71-119.

Baena Preysler, J., \& Carrión Santafé, E. (2010). Experimental Approach to the Function and Technology of Quina Side-Scrapers. In H. G. Nami (Ed.), Experiment and Interpretation of Traditional Technologies: Essays in Honor of Errett Callahan (pp. 171-202). Buenos Aires: Ediciones de Arqueología Contemporánea.

Bell, R. (1965). Archaeological Investigations at the Site El Inga, Ecuador. Quito: Casa de Cultura.

Bird, J. (1946). The Archeology of Patagonia. In J. H. Steward (Ed.), Handbook of South American Indians (pp. 17-24). Smithsonian Institution Bureau of American Ethnology, Bulletin 143, Washington DC: Smithsonian Institution.

Bird, J. (1960). Period III Stemless Points from Palli Aike and Fell's caves. Revista del In- 
stituto de Antropología, I, 297-298.

Bird, J. (1988). Travels and Archaeology in South Chile. Iowa City, IA: Iowa University Press.

Bronk Ramsey, C., \& Lee, S. (2013). Recent and Planned Developments of the Program OxCal. Radiocarbon, 55, 720-730. https://doi.org/10.1017/S0033822200057878

Bueno, L., Schmidt Dias, A., \& Steele, J. (2013). The Late Pleistocene/Early Holocene Archaeological Record in Brazil: A Geo-Referenced Database. Quaternary International, 301, 74-93.

Callahan, E. (1979). The Basics of Biface Knapping in the Eastern Fluted Point Tradition. A Manual for Flintknappers and Lithic Analysts. Archaeology of Eastern North America, 7, 1-180.

Caruso L., \& Civalero, M. T. (2014). Holocene Landscape Changes and Wood Use at Patagonia. Plant Macroremains from Cerro Casa de Piedra 7. The Holocene, 24, 188-197. https://doi.org/10.1177/0959683613516816

Caruso L., Clemente, I., \& Civalero, M. T. (2015). A Use-Wear Analysis of Wood Technology of Patagonian Hunter-Gatherers. The Case of Cerro Casa de Piedra 7, Argentina. Journal of Archaeological Science, 57, 315-321.

Castro, A., Cione, A., Civalero, M. T., \& De Nigris, M. (2012). A Fossil Shark Tooth in Early Contexts of Cerro Casa de Piedra 7, Southwest Patagonia Argentina. In L. Miotti, M. Salemme, N. Flegenheimer, \& T. Goebel (Eds.), Southbound Late Pleistocene Peopling of Latin America (pp. 165-176). College Station, TX: Center for the Study of the First Americans, Texas A\&M University.

Cattáneo, R. (2006). Tecnología Lítica del Pleistoceno Final/Holoceno medio. Un estudio de los cazadores-recolectores de la Patagonia Austral (Argentina). Oxford: BAR International Series.

Civalero, M. T. (1995). El sitio Casa de Piedra 7: Algunos aspectos de la tecnología lítica y las estrategias de movilidad. Cuadernos del Instituto Nacional de Antropología, 16, 283-296.

Civalero, M. T. (1999). Obsidiana en Santa Cruz, una problemática a resolver. In Belardi, J., Fernández, P., Goñi, R., Guráieb, \& De Nigris, M. (Eds.), Soplando en el viento (pp. 155-163). Neuquén-Buenos Aires: INAPL-Universidad del Comahue.

Civalero, M. T. (2000). Circulación, aprovechamiento de recursos líticos y estrategias de diseño en el sur patagónico. Arqueología, 10, 135-152.

Civalero, M. T. (2009). Tecnología lítica de cazadores tempranos en los contrafuertes de la Altiplanicie central santacruceña y el área lacustre cordillerana (lago Burmeister). In M. Salemme, F. Santiago, M. Alvarez, E. Piana, M. Vazquez, \& M. E. Mansur (Eds.), Arqueología de Patagonia: Una mirada desde el último confín, 1 (pp. 65-74). Ushuaia: Ediciones Utopías.

Civalero, M. T. (2016). Propuesta metodológica para el análisis del material lítico del sitio Playa Cisnes 2, provincia de Santa Cruz, Patagonia argentina. In F. Mena (Ed.), Arqueología de la Patagonia: de mar a mar (pp. 235-244). Coyhaique: Ediciones CIEP/Ñire Negro Ediciones.

Civalero, M. T., \& Aschero, C. A. (2003). Early occupations at Cerro Casa de Piedra 7, Santa Cruz Province, Patagonia Argentina. In L. Miotti, M. Salemme, \& N. Flegenheimer (Eds.), Where the South Winds Blow: Ancient Evidence for Paleo South Americans (pp. 141-147). College Station, TX: Center for the Study of the First Americans, Texas A\&M University Press.

Civalero, M. T., \& De Nigris, M. (2005). Explotación de fauna y tecnología lítica en Cerro Casa de Piedra 7, Santa Cruz. Relaciones de la Sociedad Argentina de Antropología, 
$X X X, 105-122$.

Civalero, M. T., \& Franco, N. V. (2003). Early Human Occupations in Western Santa Cruz Province, Southernmost South America. Quaternary International, 109-110, 7786.

Civalero, M. T., Borrazo, K., Bozzuto, D., Di Vruno, A., Dolce, V., Limbrunner, P., \& Lucero, M. (2007). ¿Ultimas?..excavaciones en Cerro Casa de Piedra 7, Santa Cruz. In F Oliva, N. De Grandis, \& J. Rodríguez (Eds.), Arqueología argentina en los inicios de un nuevo siglo I (pp. 329-335). Rosario: Laborde Libros.

Civalero, M. T., Bozzuto, D. L., Di Vruno, A., \& De Nigris, M. E. (2006-2007). Cerro Casa de Piedra, una fecha diferente. Cuadernos del Instituto Nacional de Antropología, 21, 259-261.

Clark, J. D. (1981). Ethno-archaeology in Ethiopia and Its Relevance for Archaeological Interpretations. In Roubet, C., Hugot, H. J. \& Souville, G. (Eds.), Festschrift for Professor L. Balout (pp. 69-79). Paris: Editions A.D.P.F.

Clark, J. D., \& Kurashina, H. (1981). A Study of the Work of a Modern Tanner in Ethiopia and Its Relevance for Archaeological Interpretation. In R. A. Gould, \& M. B. Schiffer (Eds.), Modern Material Culture: The Archaeology of Us (pp. 303-343). New York: Academic Press.

Cortegoso, V. (2014). Explotación de ambientes cordilleranos y precordilleranos del Centro-Oeste durante el Holoceno: Variabilidad espacial y temporal en la organización de la tecnología lítica. In V. Cortegoso, V. Durán, \& A. Gasco (Eds), Arqueología de ambientes de altura de Mendoza y San Juan (Argentina) (pp. 19-42). Mendoza: EDIUNC.

Crivelli Montero, E., Curzio, D., \& Silveira, M. (1993). La estratigrafía de la Cueva Traful I (Provincia del Neuquén). Praehistoria, 1, 17-160.

De Nigris, M. (2004). El consumo en grupos cazadores-recolectores. Un ejemplo zooarqueológico de Patagonia meridional. Colección Tesis Doctorales, Buenos Aires: Sociedad Argentina de Antropología.

Dibble, H. L. (1995). Middle Paleolithic Scraper Reduction: Background, Clarification, and Review of the Evidence to Date. Journal of Archaeological Method and Theory, 2, 299-368. https://doi.org/10.1007/BF02229003

Durán, V., Gil, A., Neme, G., \& Gasco, A. (2003). El Verano: Ocupaciones de 8900 años en la Cueva 1 (Santa Cruz, Argentina). In A. M. Aguerre (Ed.), Arqueología y Paleoambiente en la Patagonia Santacruceña Argentina (pp. 93-120). Buenos Aires: Búsqueda de Ayllu.

Escola, P. (2014). Proyectiles líticos en contexto: Algo más que una tecnología para la caza. In G. Politis, M. A. Gutiérrez, \& C. Scabuzzo (Eds.), Vidas Profanas-Muertes Sagradas. Estado Actual de las Investigaciones en el Sitio Arroyo Seco 2, Región Pampeana, Argentina (pp. 313-327). Olavarría: Serie Monográfica INCUAPA, Facultad de Ciencias Sociales de la Universidad del Centro de la Provincia de Buenos Aires.

Escudero, A., Davila, C., Villela, F., Troncoso, A., Méndez, C., \& López, P. (2016). Early Holocene Inland Occupation in the Semiarid North of Chile. PaleoAmerica, 2, 74-77. https://doi.org/10.1080/20555563.2015.1137678

Espinosa, S., \& Goñi, R. (1999). ¡Viven!: Una fuente de obsidiana en la provincia de Santa Cruz. In J. Belardi, P. Fernández, R. Goñi, G. Guráieb, \& M. De Nigris (Eds,), Soplando en el viento (pp. 177-188). Neuquén-Buenos Aires: INAPL-Universidad del Comahue.

Fidalgo, F., Meo Guzmán, L. M., Politis, G. G., Salemme, M., Tonni, E. P., Carbonari, J., Gómez, G., Huarte, R. A., \& Figini, A. (1986). Investigaciones arqueológicas en el sitio 2 de Arroyo Seco (Pdo. De Tres Arroyos-Pcia. De Buenos Aires-República Argentina). 
In A. Bryan (Ed.), New Evidence for the Pleistocene Peopling of the Americas (pp. 221-269). Orono: Center for the Study of the Early Man.

Flegenheimer, N., Miotti, L., \& Mazzia, N. (2013). Rethinking Early Objects and Landscapes in the Southern Cone: Fishtial-Point Concentrations in the Pampas and Northern Patagonia. In K. E. Graf, C. V. Ketron, \& M. R. Waters (Eds.), Paleoamerican Odissey (pp. 359-376). College Station, TX: Center for the Study of the First Americans.

Fugassa, M. H., Aschero, C., \& Civalero, M. T. (2005). Paleoparasitología en coprolitos del Parque Nacional Perito Moreno, provincia de Santa Cruz, Argentina. Revista Argentina de Antropología Biológica, 7, 117.

Fugassa, M. H., Beltrame, M. O., Sardella, N. H., Civalero, M. T., \& Aschero, C. (2010). Paleoparasitological Results from Coprolitos Dated at the Pleistocene-Holocene Transition as Source of Paleoecological Evidence in Patagonia. Journal of Archaeological Science, 37, 880-884.

Fugassa, M. H., Denegri, G. M., Sardella, N. H., Araújo, A., Guichón, R. A., Martinez, P. A., Civalero, M. T., \& Aschero, C. (2006). Paleoparasitological Records in Canid Coprolite from Patagonia, Argentina. Journal of Parasitology, 92, 1110-1113. https://doi.org/10.1645/GE-876R1.1

Gallagher, J. P. (1977). Contemporary Stone Tools in Ethiopia: Implications for Archaeology. Journal of Field Archaeology, 4, 407-414.

Gradín, C. J., \& Aguerre, A.M. (Eds.) (1994). Contribución a la arqueología del Río Pinturas. Pcia. de Santa Cruz. Concepción del Uruguay: Ediciones Búsqueda de Ayllu.

Gradín, C. J., Aschero, C. A., \& Aguerre, A. M. (1976). Investigaciones arqueológicas en la Cueva de las Manos. Estancia Alto Río Pinturas (prov. de Santa Cruz). Relaciones Sociedad Argentina de Antropología, X, 201-250.

Gradín, C. J., Aschero, C. A., \& Aguerre, A. M. (1987). Primeros niveles culturales en el Área Río Pinturas (Provincia de Santa Cruz, Argentina). Estudios Atacameños, 8, 118-141.

Hogg A. G., Quan, H., Blackwell, P. G., Mu, N., Buck, C. E., Guilderson, T. P., Heaton, T. J., Palmer, J. G., Reimer, P. J., Reimer, R. W., Turney, C. S., \& Zimmerman, S. R. H. (2013). SHCal13 Southern Hemisphere Calibration, 0 - 50,000 Years cal BP. Radiocarbon, 55, 1889-1903. https://doi.org/10.2458/azu_js_rc.55.16783

Hoguin, R. (2014). Secuencia cronológica y tecnología lítica en la Puna seca y salada de los Andes Centro-Sur para el holoceno temprano y medio a través del ejemplo de Susques. Relaciones de la Sociedad Argentina de Antropología, XXXIX, 333-364.

Horta, L. R., \& Aschero, C. A. (2010). Evidencias de un Paleolago Pleistoceno tardíoHoloceno temprano en el área del lago Pueyrredón, Noroeste de la provincia de Santa Cruz. In J. R. Bárcena, \& H. Chiavazza (Eds.), XVII Congreso Nacional de Arqueología Argentina (pp. 1929-1934). Mendoza: FFyL(UNCU)-INCIHUSA-CONICET.

Horta, L. R., Busnelli, J., Georgieff, S.M., \& Aschero, C. A. (2013). Landform Analysis of the Pueyrredón Lake Area in Northwestern Santa Cruz, Argentina. Quaternary International, 317, 19-33.

Horta, L. R., Georgieff, S. M., Cónsole, C., Busnelli, J., \& Aschero, C. (2011). Registros de fluctuaciones paleobatimétricas del sistema lacustre Pueyrredón-Posadas-Salitroso durante el Pleistoceno Tardío-Holoceno Temprano, noroeste de Santa Cruz, Argentina. Serie Correlación Geológica, 27, 100-109.

López Castaño, C. E. (1999). Ocupaciones tempranas en las tierras bajas tropicales del valle medio del rio Magdalena sitio 05YON002, Yondo Antioquia. Fundación de Investigaciones Arqueológicas Nacionales Banco de la República Santafé de Bogotá, 
D.C.

Lourdeau, A., Sirlei, E., \& Viana, S. A. (2014). Early Holocene Blade Technology in Southern Brazil. Journal of Anthropological Archaelogy, 35, 190-201.

Martínez Tosto, A. C., Burry, L. S., \& Civalero, M. T. (2012). Aportes paleobotánicos en la reconstrucción de paleodietas. Análisis de coprolitos del Cerro Casa de Piedra, Santa Cruz. Revista del Museo de Antropología, 5, 163-170.

Martínez Tosto, A. C., Burry, L. S., Arriaga, M.O., \& Civalero, M. T. (2016). Archaeobotanical Study of Patagonian Holocene Coprolites, Indicators of Diet, Cultural Practices and Space Use. Journal of Archaeological Science: Reports, 10, 204-211.

Nami, H. G. (1987). Cueva del Medio: Perspectivas arqueológicas para la Patagonia Austral. Anales del Instituto de la Patagonia, 17, 71-106.

Nami, H. G. (1997). Investigaciones actualísticas para discutir aspectos técnicos de los cazadores-recolectores del tardiglacial: El problema Clovis-Cueva Fell. Anales del Instituto de la Patagonia, 25, 152-186.

Nami, H. G. (1997-1998). Observaciones actuales y estilo en tecnología lítica. Arte moderno y técnicas tradicionales como una vía para el conocimiento del pasado. Relaciones de la Sociedad Argentina de Antropología, 22-23, 363-388.

Nami, H. G. (1999). Arqueología en la localidad arqueológica de Pali Aike, cuenca del río Chico, provincia de Santa Cruz. Prehistoria, 3, 189-218.

Nami, H. G. (2000). Investigaciones actualísticas y piedra tallada. I) Criterios experimentales para identificar lascas de talla bipolar: Su aplicación en la interpretación de artefactos arqueológicos de los extremos norte y sur de la Patagonia. III Congreso Argentino de Americanistas, 3, 229-270. Buenos Aires: Sociedad Argentina de Americanistas.

Nami, H. G. (2006). Experiments to Explore the Paleoindian Flake-Core Technology in Southern Patagonia. In J. Apel, \& K. Knutsson (Eds.), Skilled Production and Social Reproduction. Aspects on Traditional Stone Tool Technologies (pp. 69-80). Uppsala: Societas Archaeologica Upsaliensis (SAU) \& The Department of Archaeology and Ancient History, Uppsala University.

Nami, H. G. (2009). Avances de las investigaciones arqueológicas en la localidad arqueológica de Pali Aike, extremo sur de la provincia de Santa Cruz. In Estado actual de las investigaciones realizadas sobre patrimonio cultural en Santa Cruz (pp. 235-241). Río Gallegos: Subsecretaría de Cultura de la Provincia de Santa Cruz.

Nami, H. G. (2010). Experiments to Understand North and South American Late Pleistocene Lithic Reduction Sequences: An Actualistic and Comparative Study. In H. G. Nami (Ed.), Experiments and Interpretation of Traditional Technologies: Essays in Honor of Errett Callahan (pp. 203-253). Buenos Aires: Ediciones de Arqueología Contemporánea.

Nami, H. G. (2014). Arqueología del último milenio del Pleistoceno en el Cono Sur de Sudamérica, puntas de proyectil y observaciones sobre tecnología Paleoindia en el Nuevo Mundo. In M. Farias, \& A. Lourdeau (Eds.), Peuplement et modalités d'occupation de l'Amérique du sud: l'apport de la technologie lithique (pp. 279-336).

Nami, H. G. (2015). Experimental Observations on Some Non-Optimal Materials from Southern South America. Lithic Technology, 40, 128-146. https://doi.org/10.1179/2051618515Y.0000000004

Nami, H. G., \& Civalero, M. T. (2016). Experimentos para explorar la manufactura de instrumentos unifaciales peculiares del noroeste de la provincia de Santa Cruz. Actas del XIX Congreso Nacional de Arqueología Argentina (pp. 769-772). S. M. de Tucumán: Serie monográfica y didáctica 54, FCN e IML Universidad Nacional de Tucumán. 
Onetto, M. (1994). Análisis lítico del Alero Charcamata. In C. Gradín, \& A. M. Aguerre (Eds.), Contribución a la Arqueología del río Pinturas. Provincia de Santa Cruz (pp. 202-228). Concepción del Uruguay: Búsqueda de Ayllu.

Pagli, M., de Oliveira, E., Lucas, L., \& Lourdeau, L. (2016). Proposta de sequência tecnocultural da Serra da Capivara (Piauí) do Pleistoceno final ao Holoceno recente. Cadernos do CEOM, 29, 243-267. https://doi.org/10.22562/2016.45

Patané Aráoz, C. J., \& Restifo, F. (2016). The First Stages in the Peopling of the Salta Province, Puna Region (Northwest Argentina): A Review Based on Projectile Points. PaleoAmerica, 2, 64-66. https://doi.org/10.1080/20555563.2015.1137384

Reedy, C., \& Reedy, T. (1994). Relating Visual and Technological Styles in Tibetan Sculpture Analysis. World Archaeology, 25, 304-320. https://doi.org/10.1080/00438243.1994.9980247

Restifo, F., \& Hoguin, R. (2012). Risk and Technological Decision-Making during the Early to Mid-Holocene Transition: A Comparative Perspective in the Argentine Puna. Quaternary International, 256, 35-44.

Sacchi, M., Bozzuto, D., Horta, L., Fernández, N., De Nigris, M., Civalero, M. T., \& Aschero, C. (2016). Dataciones y circulación humana: influencia de las fluctuaciones del sistema lacustre Pueyrredón-Posadas durante el Holoceno. Revista Andes, 27.

Sackett, J. R. (1982). Approaches to Style in Lithic Archaeology. Journal of Anthropological Archaeology, 1, 59-112.

Scheinsohn, V. (2010). Down to the Bone: Tracking Prehistoric Bone Technology in Southern Patagonia. In A. Legrand-Pineau, I. Sidéra, N. Buc, E. David, \& V. Scheinsohn (Eds.), Ancient and Modern Bone Artefacts from America to Russia. Cultural, Technological and Functional Signature (pp. 1-6). Oxford: BAR International Series.

Schiffer, M., \& Skibo, J. (1987). Theory and Experiment in the Study of Technological Change. Current Anthropology, 28, 595-622. https://doi.org/10.1086/203601

Stern, C. R. (1999). Black Obsidian from Central-South Patagonia; Chemical Characteristics, Sources and Regional Distribution of Artifacts. In J. Belardi, P. Fernández, R. Goñi, G. Guráieb, \& M. De Nigris (Eds,), Soplando en el viento: Actas de las III Jornadas de Arqueología de la Patagonia (pp. 221-234). Neuquén-Buenos Aires: INAPL-Universidad del Comahue.

Temme, M. (1982). Excavaciones en el sitio precerámico de Cubilán (Ecuador). Miscelánea Antropológica Ecuatoriana, 2, 135-164.

Weedman Arthur, K. J. (2008). The Gamo hideworkers of Southwestern Ethiopia and Cross Cultural Comparisons. Anthropozoologica, 43, 67-98.

Whittaker, J. C. (1994). Flintknapping: Making and Understanding Stone Tools. Austin: University of Texas Press. 
Submit or recommend next manuscript to SCIRP and we will provide best service for you:

Accepting pre-submission inquiries through Email, Facebook, LinkedIn, Twitter, etc. A wide selection of journals (inclusive of 9 subjects, more than 200 journals)

Providing 24-hour high-quality service

User-friendly online submission system

Fair and swift peer-review system

Efficient typesetting and proofreading procedure

Display of the result of downloads and visits, as well as the number of cited articles Maximum dissemination of your research work

Submit your manuscript at: http://papersubmission.scirp.org/

Or contact ad@scirp.org 